\title{
TECHNOLOGICAL ASYMMETRY AMONG FOREIGN INVESTORS AND MODE OF ENTRY
}

\author{
BEATA S. JAVORCIK and KAMAL SAGGI*
}

\begin{abstract}
How does the preferred entry mode of foreign investors depend on their technological capability relative to that of their rivals? This article develops a simple model of entry mode choice and evaluates its main testable implication using data on foreign investors in Eastern European countries and the successor states of the Soviet Union. The model considers competition between two asymmetric foreign investors and captures the following trade-off: while a joint venture (JV) helps a foreign investor secure a better position in the product market vis-à-vis its rival, it also requires that profits be shared with the local partner. The model predicts that the efficient foreign investor is less likely to choose a JV and more likely to enter directly relative to the inefficient investor. Our empirical analysis supports this prediction: foreign investors with more sophisticated technologies and marketing skills (relative to other firms in their industry) tend to prefer direct entry to JVs. This empirical finding is robust to controlling for host country-specific effects and other commonly cited determinants of entry mode. (JEL F13, F23, O32)
\end{abstract}

\section{INTRODUCTION}

During the past several decades, there has been a significant change in the attitudes of many countries toward inflows of foreign direct investment (FDI). From being viewed as exploiters, foreign investors are now welcomed as a source of new technologies, know-how, better management, and marketing techniques. One only needs to consider the large-scale economic liberalization that has been undertaken by Eastern European transition economies and the successor states of the Soviet Union to appreciate the reversal in attitudes toward FDI that has occurred in the world. The increasingly liberal attitude toward FDI has been accompanied by renewed interest among policy makers and academic researchers in the relationship between

*The authors thank an anonymous referee, an associate editor, the editor, and Dann Millimet for helpful comments. All errors are our own.

Javorcik: Reader, Department of Economics, University of Oxford, Manor Road Building, Manor Road, Oxford OX1 3UQ, UK. Phone (44 1865) 271-065, Fax (44 1865) 285-900, E-mail beata.javorcik@economics.ox.ac.uk

Saggi: Department of Economics, Southern Methodist University, Dallas, TX 75275-0496. Phone 214-7683274, Fax 214-768-1821, E-mail ksaggi@ smu.edu the technology transfer and the entry mode used by foreign investors. ${ }^{1}$

An interesting finding in the existing empirical literature on international technology transfer is that the technologies of joint ventures (JVs) tend to be of an older vintage relative to those employed by wholly owned subsidiaries of multinational firms (Mansfield and Romeo 1980). A possible explanation for this finding is that firms are reluctant to share stateof-the-art technologies with local partners in foreign countries due to the fear of potential

1. There are several reasons for this interest. For instance, the consequences of restrictions on foreign ownership that used to be prevalent in many developing countries and are still present in some of them are likely to depend on whether mode choice is systematically related to technology transfer. Similarly, the degree of spillovers from FDI may also vary with the mode of investment (Blomström and Sjöholm 1999; Javorcik 2004a; Javorcik and Spatareanu 2008).

\section{ABBREVIATIONS}

EBRD: European Bank for Reconstruction and Development

FDI: Foreign Direct Investment GDP: Gross Domestic Product

IPR: Intellectual Property Right

JV: Joint Venture 
competition. ${ }^{2}$ However, this explanation ignores the fact that firms have an incentive to utilize their best technologies to compete more effectively with their rivals. In other words, to fully understand the relationship between mode choice and technology transfer, one needs to account for competitive pressures among investors. In this article, we investigate the following question both theoretically and empirically: do foreign firms that possess technologies superior to their rivals' prefer direct entry to JVs? We develop a simple duopoly model of mode choice and evaluate its main finding empirically by using data from a 1995 survey of foreign investors in Eastern European transition economies and the former Soviet republics conducted by the European Bank for Reconstruction and Development (EBRD).

A casual examination of our sample suggests that there might indeed be a systematic relationship between a firm's relative technological sophistication and its preferred mode of entry. We measure a firm's technological sophistication by the ratio of its research and development (R\&D) intensity (R\&D expenditures as a percentage of total sales) to the average $R \& D$ intensity of major firms operating in the same industry in industrialized countries. Figure 1 presents the average technological sophistication index of foreign investors entering directly and via JVs in the top five investment destinations in our sample broken down by industry. As is clear, JVs are associated with lower values of the index in all five of these countries except Russia. For example, in the case of the Czech Republic and Hungary, JVs are associated with lower values of the index in eight of nine industries.

Similarly, as Figure 2 indicates, a crosscountry comparison of the average technological sophistication of investors operating JVs and subsidiaries for several broadly defined industries reveals a similar pattern: in food, machinery, electronics, and automobile industries, investors with higher technological sophistication seem to prefer direct entry to JVs.

2. This fear may be particularly strong in corrupt countries where disputes between JV partners are unlikely to be adjudicated fairly (Javorcik and Wei 2009). For an alternative explanation, see Ramachandran (1993). In her model, the effort expended by the local agent determines the extent of technology transfer, and such effort is undersupplied in a JV due to double moral hazard created by profit sharing. Mattoo, Olarreaga, and Saggi (2004) provide a comparative analysis of technology transfer under two modes of FDI: direct entry and acquisition.
In addition to these pointers from our sample, two prominent stylized facts regarding FDI are relevant for our analysis. First, it is well known that foreign investors often choose JVs to team up with local partners that possess complementary skills and assets. For example, in a survey of JVs in developing countries, more than $65 \%$ of the foreign respondents rated knowledge of local politics, government regulations, local customs, and local markets as important considerations for seeking local partners (Miller et al. 1996). Of course, while local partners in JVs often bring much needed skills to a project, they also require compensation for their services through some sort of profit sharing. The second stylized fact worth noting is that multinationals operate mostly in oligopolistic markets and are quite responsive to each other's decisions (Caves 1996). Thus, it is important to capture the strategic decision making involved in the choice of entry mode.

Motivated by these considerations and Figures 1 and 2, we construct a highly stylized model with the goal of deriving an empirically testable implication that relates the entry mode chosen by an investor to its technological position visà-vis its rivals. In our duopoly model, investing firms are technologically asymmetric and two independent parameters quantify the rentsharing aspect and the complementarity of JV partners. The main result is that the more technologically advanced a foreign investor, the more likely it is to choose direct entry over a JV. In fact, in equilibrium, it is never the case that the technologically advanced firm forms a JV and its rival firm chooses direct entry. ${ }^{3}$ Our simple model adds value to the theoretical literature on mode choice by considering competition between asymmetric investors. By contrast, most existing models typically consider the case of a single investor, and when they do consider multiple investors, they either do not allow for JVs or consider only symmetric investors (Asiedu and Esfahani 2001; Ethier and Markusen 1996; Horstmann and Markusen 1992; Markusen 2001).

3. One has to be careful here: the model does not say that the efficient firm never chooses a JV but rather that, if the inefficient firm does not choose a JV, the efficient firm will never do so either. There certainly exist parameter values for which both firms opt for a JV. 
FIGURE 1

Technological Sophistication Index of Investors Undertaking JVs versus Direct Entry by Host Country
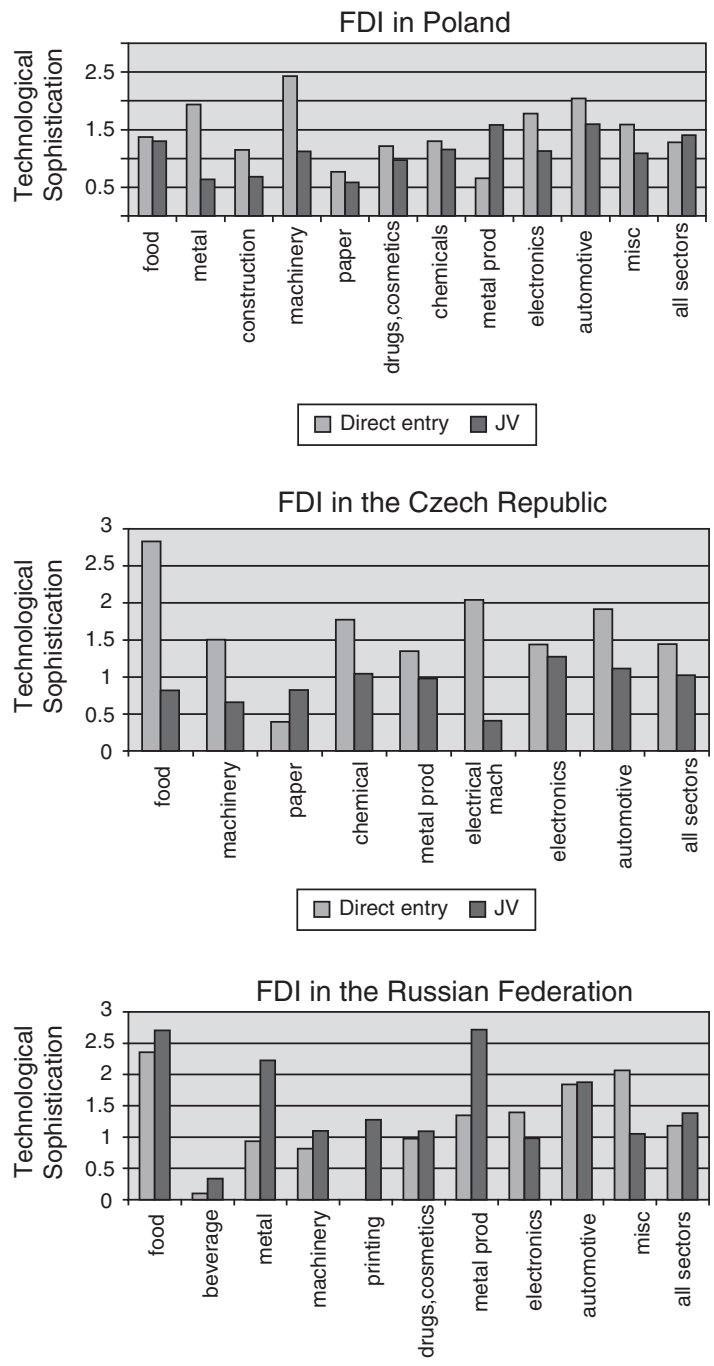

$\square$ Direct entry $\square \mathrm{JV}$

To evaluate the empirical validity of our main result, we use a unique data set based on a survey conducted by the EBRD among major companies in the world asking about their investments (if any) in transition countries of Eastern Europe and the former Soviet Union. The survey results are supplemented with firm-specific information from the Worldscope database. ${ }^{4}$ We

4. This data set was also used by Javorcik (2004b).
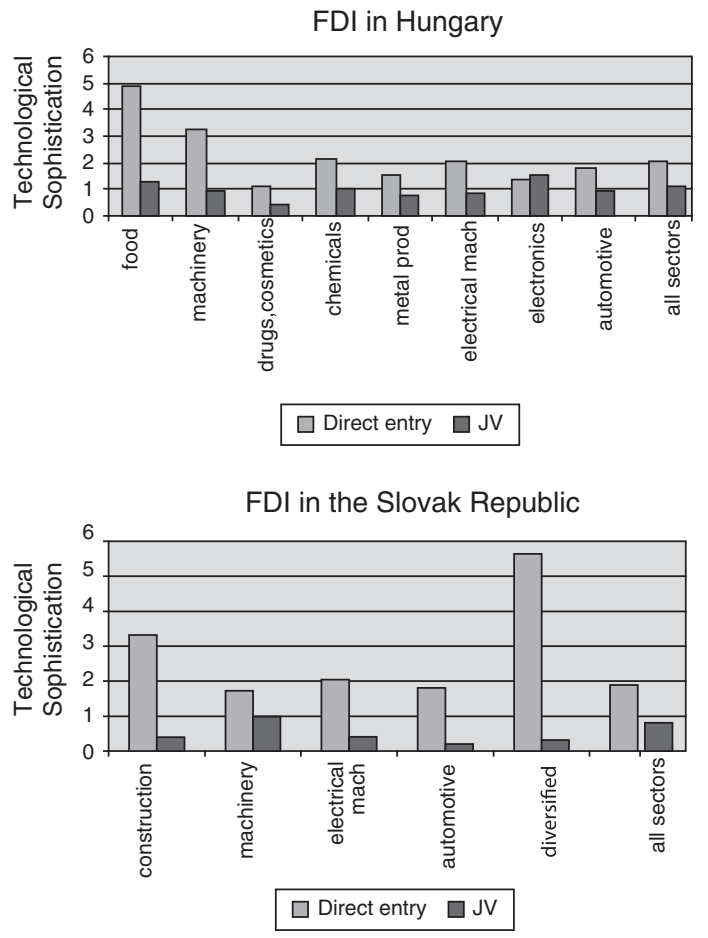

estimate a probit model with the dependent variable taking on the value of 1 if investor $i$ engages in a JV with a local partner in country $k$ and 0 if it chooses direct entry. The results lend support to our theoretical model by indicating that firms possessing more sophisticated technologies (relative to other firms operating worldwide in their industry) are less likely to engage in JVs and more likely to enter the market directly. The same is true of firms with above-average marketing sophistication, which 
FIGURE 2

Technological Sophistication Index of Investors Undertaking JVs versus Direct Entry by Industry

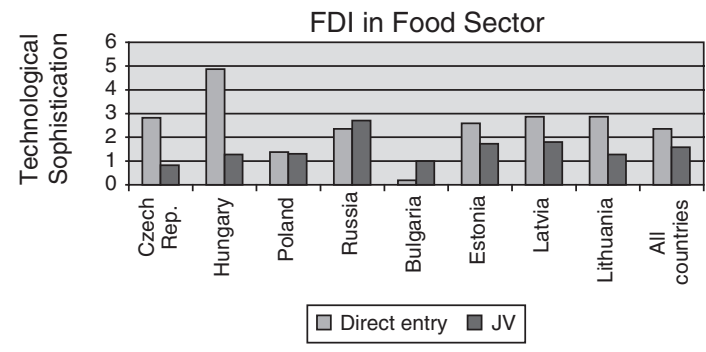

FDI in Electronics Sector

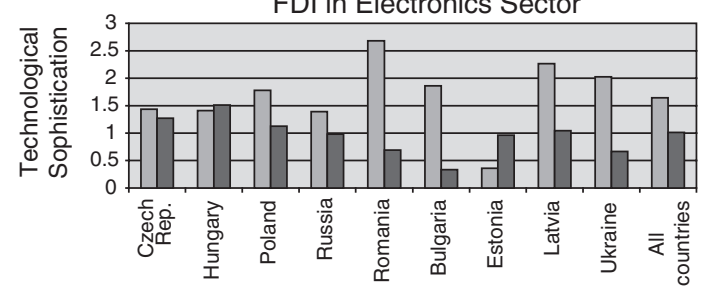

$\square$ Direct entry $\square \mathrm{JV}$

is also related to the firm's endowment of intangible assets. Coefficients on both variables (relative technological and marketing sophistication) are statistically significant and remain so even when entered into the same equation. These results are robust to the inclusion of other investor-specific characteristics as well as host country and industry fixed effects. However, when both host country and industry fixed effects are included in the same equation, only the technological sophistication index remains significant.

As a further robustness check, not employed in the earlier studies of mode choice, ${ }^{5}$ we estimate a two-stage model that captures two choices: (1) the decision to undertake FDI in a given country and (2) the choice between a direct entry and a JV, conditional on FDI taking place. In other words, we control for selection bias that may be present when only actual investment projects are considered and observations pertaining to firm-country pairs with no investment are discarded. We also note that our results are robust to controlling for country characteristics such as the evolution of the transition process and the distance between the source and the host country. Finally, we check whether our results could be driven by the

5. With the exception of Javorcik and Wei (2009).

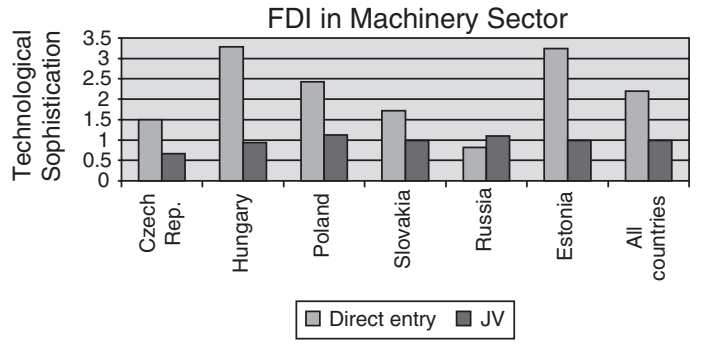

FDI in Automobile Sector

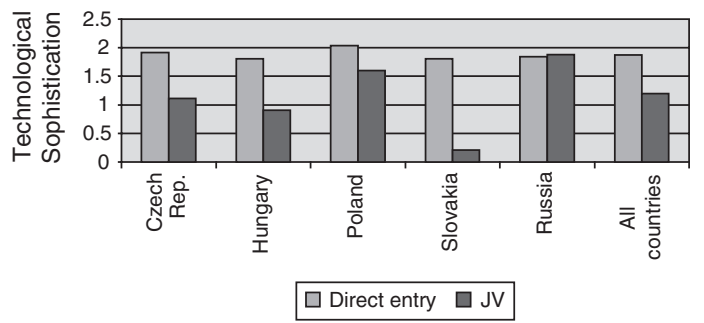

possibility that the link between the entry mode and the technological sophistication reflects fear of technology leakage in countries with a weak protection of intellectual property rights (IPRs). This, however, does not seem to be the case. While we find that foreign investors are attracted to locations with stronger IPR protection, we find no evidence of IPR legislation affecting the choice of entry mode.

While existing empirical studies of entry mode find a negative relationship between the importance of firm-or industry-level intangible assets and the probability of entering through a JV (Asiedu and Esfahani 2001; Gatignon and Anderson 1988; Gomezs-Casseres 1989), this article focuses on technological and marketing sophistication of investing firms relative to other firms operating in the industry worldwide. Thus, we concentrate on intraindustry differences as a determinant of mode choice in addition to controlling for interindustry effects. The only existing study that considers intraindustry differences, Javorcik (2006), differs in focus as its objective is to compare high- and lowtechnology industries in this respect. Moreover, we employ a data set that is unique in the extent of its coverage. Previous studies on the choice of entry mode use data on FDI originating in one source country (i.e., Sweden in the case of Blomström and Zejan 1991, or the United States 
as in the case of Asiedu and Esfahani 2001) or on FDI entering a single host country (typically the United States). Our data set covers investment projects undertaken in multiple economies by investors from all over the world.

This article is structured as follows. The next section presents our theoretical model of entry mode choice. Section III discusses our empirical strategy, the data used, and the results obtained. The last section concludes. Details of theoretical derivations and the data used are collected in separate appendices.

\section{MODEL}

In this section, we develop a partial-equilibrium duopoly model of mode choice. Two foreign firms are considering entry into a market where the inverse demand function is given by $p(q)$ and $q$ denotes total output. Each firm can enter the market directly and produce the good on its own or form a JV with a local partner who lacks the ability to produce the good alone. Let $e$ denote direct entry and $j$ a JV. The technology of production and distribution depends on mode choice in the following way. If firm $i$ decides to enter the market directly (i.e., by establishing a wholly owned subsidiary), it requires $\alpha_{i}$ units of labor for producing each unit and $\beta_{i}$ units for distributing it. Thus, under direct entry, firm $i$ 's marginal cost equals

$$
C_{i}^{e}=\alpha_{i}+\beta_{i}
$$

By definition, under a JV, firm $i$ must share some rents with its local partner. Let firm $i$ 's share of the total profit of the JV be given by $\theta$, where $\theta \in[0,1] .^{6}$ The advantage of forming a $\mathrm{JV}$ is that the local partner brings knowledge and expertise about the host country market, which lowers the unit labor requirement in distribution to $\delta \beta_{i}$, where $\delta \in[0,1]^{7}$ The smaller is $\delta$, the

6. Since in our data set we do not have information regarding the equity structure of JVs, we leave $\theta$ as an exogenous parameter. Al-Saadon and Das (1996) construct a model of an international JV in which ownership shares are endogenously determined as the outcome of bargaining between a multinational firm and a single host firm. For analyses of policy restrictions on the degree of foreign ownership, see Mattoo, Olarreaga, and Saggi (2004) and Klimenko and Saggi (2007).

7. Note that $\delta$ is intended to represent more generally the contribution of the local partner to the JV. Such contribution may take the form not only of access to distribution networks but also of knowledge of local tastes, suppliers, and legislation as well as an improved ability to navigate through the bureaucratic maze in the host country. lower a JV's unit cost of distribution. Thus, under a JV, firm $i$ 's unit cost is given by

$$
C_{i}^{j}=\alpha_{i}+\delta \beta_{i} .
$$

To generate technological asymmetry between foreign investors, assume that $\alpha_{1} \leq \alpha_{2}$ and $\beta_{1} \leq$ $\beta_{2}$. Note that, holding constant the mode of entry, Firm 1 has a lower marginal cost than Firm 2.

Now consider the following market entry game. In the first stage, each firm chooses between the two modes of entry (JV vs. direct entry). Next, both firms compete in quantities (Cournot-Nash competition). Firm $i$ 's profit function at the output stage is given by $\pi_{i}\left(q_{i}, q_{-i}\right)=$ $\left(p(q)-c_{i}\right) q_{i}$, and the associated first-order condition for profit maximization can be written as follows:

$$
\frac{\partial \pi_{i}\left(q_{i}, q_{-i}\right)}{\partial q_{i}}=p+p^{\prime} q_{i}-c_{i}=0 .
$$

Solving the above first-order conditions yields the equilibrium in the product market. Let the pair $(x, y)$ denote the regime where Firm 1 chooses entry mode $x$ and Firm 2 chooses entry mode $y$, where $x, y=e, j$. Furthermore, let $\pi_{1}^{e y}$ denote Firm 1's equilibrium profit under regime $(e, y)$ and $\theta \pi_{1}^{j y}$ under regime $(j$, $y$ ). Similarly, interpret Firm 2's payoffs $\pi_{2}^{x e}$ and $\theta \pi_{2}^{x j}$.

Since Firm 1 is more efficient than Firm 2, it is always the case that $\pi_{1}^{e y} \geq \pi_{2}^{x e}$ and $\theta \pi_{1}^{j y} \geq$ $\theta \pi_{2}^{x j}$ : under the same entry mode, Firm 1 has higher total profit than Firm 2. Of course, it need not be the case that Firm 1 has higher profit when it chooses direct entry and when Firm 2 chooses a JV. This ranking depends on the parameters of the model.

To describe the subgame perfect equilibrium of this model, we need two definitions. Denote the change in firm $i$ 's profit that results from its switching from a direct entry to a JV, given that its rival adopts direct entry by $u_{i}$ :

$$
u_{1} \equiv \theta \pi_{1}^{j e}-\pi_{1}^{e e} \text { and } u_{2} \equiv \theta \pi_{2}^{e j}-\pi_{2}^{e e} .
$$

Each firm can gain market share at the expense of its rival by forming a JV and lowering its marginal cost. Of course, to do so, a firm must forsake some of the total profit of the $\mathrm{JV}$ to the local partner. Firm $i$ prefers a JV to a direct entry given that its rival chooses direct entry iff $u_{i}>0$. We will say that firm $i$ has a unilateral incentive for $a J V$ iff $u_{i}>0$. 
Let $\Delta_{i}$ denote the change in firm $i$ 's profit that results from its switching from a direct entry to a $\mathrm{JV}$, given that its rival forms a JV:

$$
\Delta_{1} \equiv \theta \pi_{1}^{j j}-\pi_{1}^{e j} \text { and } \Delta_{2} \equiv \theta \pi_{2}^{j j}-\pi_{2}^{j e} .
$$

A firm has a motive for forming a $\mathrm{JV}$ in response to a $\mathrm{JV}$ by its rival because it too can lower its cost and regain some of its lost market share. The function $\Delta_{i}$ measures the strength of this motive. We will say that firm $i$ has a competitive incentive for a JV iff $\Delta_{i}>0$. Using these two sets of incentive functions, the subgame perfect equilibrium of the model can be described in a succinct way.

DEFINITION 1. The equilibrium mode choice of the two firms is as follows: (1) both firms choose direct entry $(e, e)$ iff $u_{i} \leq 0,(2)$ Firm 1 chooses direct entry, while Firm 2 a JV $(e, j)$ iff $\Delta_{1} \leq 0$ and $u_{2}>0$, (iii) both firms choose a $J V(j, j)$ iff $\Delta_{i} \geq 0$, and (iv) Firm 1 chooses a $J V$ and Firm 2 direct entry $(j, e)$ iff $u_{1}>0$ and $\Delta_{2}<0$.

Our main interest is in relating a firm's preferred mode of entry to its technological capability relative to its rival. To this end, we examine how the likelihood of a particular regime being an equilibrium changes with a change in the underlying technology of the two firms. The "likelihood" of a regime is measured by the area of the parameter space over which that regime emerges as an equilibrium. For example, if we say that a change in some underlying parameter makes it more likely that a firm has a unilateral incentive for a JV, we mean that the parameter space over which the function $u_{i}$ is positive increases.

To facilitate analytical derivations and comparisons of the incentive functions, assume that the demand function is linear: $p=a-b q$.

PROPOSITION 1. An increase in a firm's marginal cost (caused due to an increase in either $\alpha_{i}$ or $\beta_{i}$ ) makes it more likely that a firm has a unilateral as well as a competitive incentive for a JV. Similarly, an increase in the marginal cost of its rival makes it less likely that the firm has a unilateral or a competitive incentive for a $J V^{8}$

A corollary to the above result can also be stated.

8. Proofs of proposition 1 and corollary 1 are in Appendix I.
FIGURE 3

Equilibrium Mode Choice

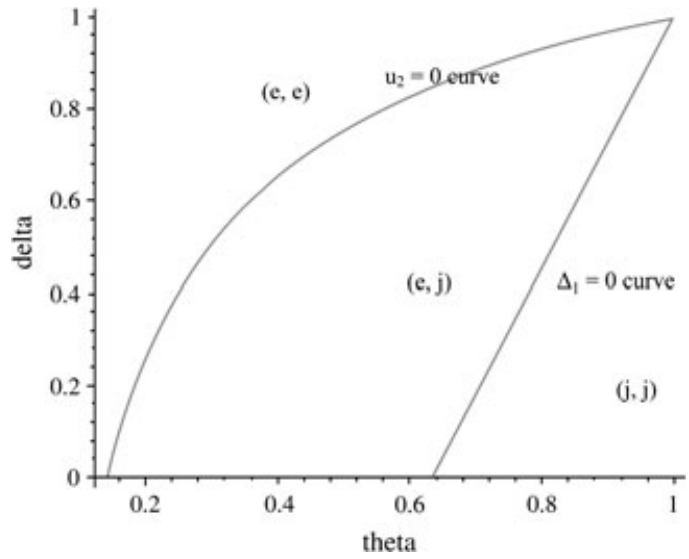

COROLLARY 1. Whenever Firm 1 has unilateral incentive for a JV, so does Firm 2. Furthermore, the regime $(j, e)$ where Firm 1 chooses a $J V$ and Firm 2 direct entry does not constitute an equilibrium.

Corollary 1 implies that we cannot have an equilibrium in which only the efficient firm (i.e., Firm 1) forms a JV. Figure 3 illustrates a typical equilibrium pattern in $(\delta, \theta)$ space. $^{9}$ In this figure, we plot the zero contours for the incentive functions $u_{2}$ and $\Delta_{1}$. The other incentive functions are omitted from this figure since they are not needed to describe the equilibrium mode choice. For example, the function $u_{1}$ is not plotted since it lies below all the other three functions and does not play a critical role in determining the equilibrium mode choices of firms. Furthermore, the fact that $u_{1}$ lies below $\Delta_{2}$ implies that if the efficient firm has a unilateral incentive for a JV, the inefficient firm has a competitive incentive to do the same, thereby ruling out $(j, e)$ as an equilibrium entry regime.

Two properties of Figure 3 are worth noting. First, the zero contours for all incentive functions are upward sloping. This common property of all zero contours follows from the model's fundamental trade-off: as the local partner's contribution becomes less valuable (i.e., as $\delta$ increases), each firm requires a higher share $\theta$

9. The parameters used for this figure are as follows: $a=10, \alpha_{1}=1, \beta_{1}=1, \alpha_{2}=2$, and $\beta_{2}=2.5$. There is nothing special about these parameter values except that they give a clean figure. The propositions and corollaries stated in the article hold for all permissible parameter values. 
of the JV's total profit if it is to remain indifferent between a JV and a direct entry. Second, higher profit contours lie in the southeast region: an increase in $\theta$ and a decrease in $\delta$ make a JV more attractive relative to direct entry. ${ }^{10}$

Figure 3 can be divided into three regions. Above the zero contour for the $u_{2}$ function, $(e, e)$ is the equilibrium. In this region, $\delta$ is large and $\theta$ is small so that the local firm receives a large share of the total profit of the JV even though it does not make a valuable contribution to the $\mathrm{JV}$. As a result, in this region, direct entry is the dominant mode of entry for both firms. In the region between the zero contours for the $u_{1}$ and the $\Delta_{2}$ functions, $(e, j)$ is the equilibrium: here, the contribution of the local partner is not large enough for Firm 1 to opt for a JV, whereas it is sufficient to induce Firm 2 to choose a JV. Finally, in the region below the zero contour for the $\Delta_{2}$ function, $(j, j)$ is the equilibrium: here, the local partner's expertise really matters, and the profit share of foreign firms is large (making a JV attractive to them).

The model presented above shows how the incentives of firms to choose JVs over direct entry vary with their technological capabilities. In a broad sense, the main empirical prediction of the model is that the more technologically sophisticated a firm is relative to its rivals, the less likely it is to enter the market via a JV. We now turn to an econometric verification of this prediction.

\section{EMPIRICAL EVIDENCE}

In this section, we test the main prediction of the theoretical model. The empirical work is described in three steps. We first present some summary statistics, then discuss our econometric specification and report our regression results.

\section{A. Summary Statistics}

As noted earlier, the data set used in this study is based on the EBRD survey of foreign investors supplemented with the information obtained from the Worldscope database. In January 1995, a brief questionnaire was sent out to all companies (about 9,500) listed

10. As should be clear, the model has many exogenous parameters, and figures corresponding to Figure 3 can be drawn in the space of other parameters as well. Figure 3 has been drawn in the $(\delta, \theta)$ space because both of these parameters lie between 0 and 1, thereby allowing a clean representation of equilibrium. in Worldscope. Responses were obtained from 1,405 firms, which reported whether they had undertaken investments in Eastern European transition economies and the successor states of the Soviet Union. Our sample covers 21 host countries. Further details about the survey and the data are given in Appendix II.

Table 1 presents the breakdown of entry modes chosen by foreign investors in our sample for each of the host countries. Note that JVs outnumber direct entries in most host countries and constitute $59 \%$ of all projects.

Table 2 presents the percentage of foreign investors who chose a given entry mode in each industry in our sample. The figures indicate that JVs were the dominant form of investment in a majority of industries. However, it is striking that in the drugs, cosmetics, and health care products sector, only $12 \%$ of all projects were JVs, while direct entries accounted for $88 \%$ of investments. Similarly, wholly owned projects constituted $84 \%$ of all investments in the beverage sector. It is worth noting that the drugs, cosmetics, and health care products sector is the most R\&D-intensive industry in our sample, while the beverage sector relies heavily on advertising and investments in marketing.

TABLE 1

Entry Modes Chosen by Investors in the Sample

\begin{tabular}{lrrr}
\hline Host Country & Direct Entry & JV & Total \\
\hline Russia & 29 & 72 & 101 \\
Poland & 45 & 60 & 105 \\
Czech Republic & 47 & 43 & 90 \\
Hungary & 41 & 37 & 78 \\
Slovak Republic & 16 & 22 & 38 \\
Ukraine & 5 & 17 & 22 \\
Estonia & 8 & 16 & 24 \\
Romania & 10 & 14 & 24 \\
Bulgaria & 11 & 10 & 21 \\
Latvia & 6 & 10 & 16 \\
Slovenia & 3 & 10 & 13 \\
Kazakhstan & 6 & 8 & 14 \\
Lithuania & 5 & 6 & 11 \\
Croatia & 4 & 6 & 10 \\
Belarus & 3 & 4 & 7 \\
Georgia & 2 & 4 & 6 \\
Uzbekistan & 1 & 4 & 5 \\
Albania & 1 & 3 & 4 \\
Macedonia FYR & 1 & 2 & 3 \\
Azerbaijan & 1 & 1 & 2 \\
Moldova & 0 & 1 & 1 \\
Total & 245 & 350 & 595 \\
\hline & & &
\end{tabular}


TABLE 2

Industry Breakdown of Entry Modes Chosen by Investors in the Sample

\begin{tabular}{|c|c|c|c|}
\hline Industry & $\begin{array}{l}\text { Direct Entry as \% of All } \\
\text { Projects in the Industry }\end{array}$ & $\begin{array}{l}\text { JVs as \% of All } \\
\text { Projects in the } \\
\text { Industry }\end{array}$ & $\begin{array}{l}\text { Total No. of } \\
\text { Projects in } \\
\text { the Industry }\end{array}$ \\
\hline Recreational products & 100.0 & 0.0 & 5 \\
\hline $\begin{array}{l}\text { Drugs, cosmetics, and } \\
\text { health care products }\end{array}$ & 87.9 & 12.1 & 58 \\
\hline Beverages & 84.2 & 15.8 & 19 \\
\hline Electrical & 67.7 & 32.3 & 31 \\
\hline Apparel & 50.0 & 50.0 & 2 \\
\hline Printing and publishing & 50.0 & 50.0 & 4 \\
\hline Metal products & 42.1 & 57.9 & 19 \\
\hline Food & 40.4 & 59.6 & 57 \\
\hline Automotive & 40.0 & 60.0 & 25 \\
\hline Textiles & 40.0 & 60.0 & 5 \\
\hline Metal & 33.3 & 66.7 & 27 \\
\hline Machinery and equipment & 32.2 & 67.8 & 90 \\
\hline Electronics & 32.1 & 67.9 & 78 \\
\hline Aerospace & 22.2 & 77.8 & 9 \\
\hline Chemicals & 22.0 & 78.0 & 59 \\
\hline Paper & 19.0 & 81.0 & 21 \\
\hline Diversified & 4.8 & 95.2 & 21 \\
\hline Tobacco & 0.0 & 100.0 & 5 \\
\hline Total & 41.5 & 58.5 & 595 \\
\hline
\end{tabular}

Table 3 compares the average R\&D intensity of investors engaged in direct entry with that of investors sharing ownership in each three-digit SIC (Standard Industrial Classification) sector. The sectors are grouped into high-, medium, and low-technology category following the classification used by Blomström, Lipsey, and Ohlsson (1991).

As Table 3 indicates, in all but one hightechnology industry, investors undertaking direct entry are on average more $R \& D$ intensive than those sharing ownership. For instance, in the drugs sector, the average value of $\mathrm{R} \& \mathrm{D}$ spending is equal to $15.7 \%$ of sales in the case of direct entry and $10.6 \%$ in the case of JVs. For the communications equipment, the corresponding figures are $13.3 \%$ and $5.6 \%$. And in the case of electronic components and accessories, $5.6 \%$ and $3.4 \%$. In medium-technology industries, which include industrial chemicals, motor vehicles, household appliances, and so forth, in half of the sectors in which both modes are present, investors entering a host country directly are characterized by a higher level of $R \& D$ efforts. The average $R \& D$ outlays are equal to $3.8 \%$ of sales for direct entry and 3.2 for JVs. In low-technology sectors, this is true in 10 of 16 cases. In each of the three groupings, the average R\&D intensity of firms entering directly is higher than that of firms engaged in JVs.

\section{B. Econometric Specification}

Denote a firm by $i$ and a country by $k$ and define a binary variable $J V_{i k}$ such that

$$
J V_{i k}= \begin{cases}1 & \text { if } J V_{i k}^{*}>0 \\ 0 & \text { if } J V_{i k}^{*} \leq 0\end{cases}
$$

where $J V_{i k}^{*}$ is unobserved and it determines the attractiveness of a JV relative to direct entry to firm $i$ while investing into country $k$. We further posit that

$$
J V_{i k}^{*}=\boldsymbol{W}_{i} \Theta+\beta t_{i}+\delta_{k}+\varepsilon_{i k},
$$

where $t_{i}$ is an index of technological sophistication of firm $i, W_{i}$ is the vector of other firm-specific determinants of the mode choice and $\delta_{k}$ captures country fixed effects. The above equation is estimated using a probit model with the dependent variable taking on the value of 1 if the project undertaken by firm $i$ in country $k$ is a JV and 0 if it is direct entry. Our model predicts that $\beta<0$.

The choice of explanatory variables employed in the estimation is driven by the predictions of 
TABLE 3

R\&D Intensity of FDI Projects in Three-Digit SIC Industries

\begin{tabular}{|c|c|c|c|c|}
\hline & SIC Code & JVs & Direct Entry & All \\
\hline \multicolumn{5}{|l|}{ High-technology sectors } \\
\hline Drugs & 283 & 10.62 & 15.71 & 15.23 \\
\hline Measuring and controlling devices & 382 & 9.94 & 9.08 & 9.61 \\
\hline Aircraft and parts & 372 & 7.48 & 9.44 & 8.08 \\
\hline Communications equipment & 366 & 5.60 & 13.31 & 7.06 \\
\hline Medical instruments and supplies & 384 & 4.58 & 5.07 & 4.99 \\
\hline Electronic components and accessories & 367 & 3.39 & 5.63 & 4.14 \\
\hline Computer and office equipment & 357 & 4.09 & & 4.09 \\
\hline Search and navigation equipment & 381 & 3.20 & & 3.20 \\
\hline Average & & 6.36 & 12.67 & 9.54 \\
\hline \multicolumn{5}{|l|}{ Medium-technology sectors } \\
\hline Refrigeration and service machinery & 358 & & 7.26 & 7.26 \\
\hline Electric distribution equipment & 361 & 7.26 & & 7.26 \\
\hline Hose, belting, gasket, and packing & 305 & 6.00 & 6.00 & 6.00 \\
\hline Plastics materials and synthetics & 282 & 4.65 & 4.86 & 4.71 \\
\hline Special industry machinery & 355 & 4.22 & 5.68 & 4.70 \\
\hline Industrial inorganic chemicals & 281 & 4.09 & 6.23 & 4.46 \\
\hline Motor vehicles and equipment & 371 & 3.91 & 4.49 & 4.17 \\
\hline Railroad equipment & 374 & 1.49 & 4.60 & 3.05 \\
\hline Household audio and video equipment & 365 & 5.79 & 1.03 & 2.93 \\
\hline Metalworking machinery & 354 & 2.68 & 2.56 & 2.66 \\
\hline Soap, cleaners, and toilet goods & 284 & 2.60 & & 2.60 \\
\hline General industrial machinery & 356 & 2.30 & & 2.30 \\
\hline Ship and boat building and repair & 373 & 2.14 & & 2.14 \\
\hline Engines and turbines & 351 & 2.11 & 2.11 & 2.11 \\
\hline Construction and related machinery & 353 & 1.83 & 2.49 & 2.03 \\
\hline Industrial machinery, nec & 359 & & 1.75 & 1.75 \\
\hline Miscellaneous manufactures & 399 & 1.59 & 1.59 & 1.55 \\
\hline Miscellaneous chemical products & 289 & 1.31 & & 1.31 \\
\hline Miscellaneous plastic products, nec & 308 & 1.22 & 0.11 & 1.11 \\
\hline Farm and garden machinery & 352 & 0.00 & 3.68 & 0.74 \\
\hline Electric lighting wiring equipment & 364 & 0.67 & & 0.67 \\
\hline Rubber and plastics footwear & 302 & 0.00 & 0.00 & 0.00 \\
\hline Average & & 3.21 & 3.76 & 3.35 \\
\hline \multicolumn{5}{|l|}{ Low-technology sectors } \\
\hline Printing trade services & 279 & & 5.25 & 5.25 \\
\hline Preserved fruits and vegetables & 203 & 4.24 & & 4.24 \\
\hline Broadwoven fabric mills, wool & 223 & 4.00 & & 4.00 \\
\hline Nonferrous rolling and drawing & 335 & 1.54 & 5.11 & 3.16 \\
\hline Heavy construction, excluding highway & 162 & & 2.70 & 2.70 \\
\hline Electrical work & 173 & 2.67 & & 2.67 \\
\hline Copper ores & 102 & 1.75 & 2.84 & 2.29 \\
\hline Cutlery, hand tools, and hardware & 342 & 2.22 & 2.28 & 2.27 \\
\hline Nonresident building construction & 154 & 1.25 & 2.94 & 1.93 \\
\hline Miscellaneous food and kindred products & 209 & & 1.86 & 1.86 \\
\hline Sugar and confectionery products & 206 & & 1.83 & 1.83 \\
\hline Miscellaneous metal ores & 109 & 1.73 & & 1.73 \\
\hline Manifold business forms & 276 & 1.43 & & 1.43 \\
\hline Miscellaneous textile goods & 229 & 1.40 & & 1.40 \\
\hline Clay, ceramic, and refractory minerals & 145 & 1.35 & & 1.35 \\
\hline
\end{tabular}


TABLE 3

Continued

\begin{tabular}{lcccc}
\hline & SIC Code & JVs & Direct Entry & All \\
\hline Secondary nonferrous metals & 334 & & 1.34 & 1.34 \\
Primary nonferrous metals & 333 & 1.23 & 1.23 & 1.23 \\
Iron ores & 101 & & 1.21 & 1.21 \\
Miscellaneous converted paper products & 267 & 0.21 & $\mathbf{1 . 3 4}$ & 1.15 \\
Miscellaneous nonmetallic mineral products & 329 & 0.76 & $\mathbf{2 . 4 3}$ & 1.13 \\
Metal cans and shipping containers & 341 & 1.20 & 0.79 & 0.99 \\
Blast furnace and basic steel products & 331 & 0.93 & & 0.93 \\
Meat products & 201 & 0.79 & $\mathbf{0 . 9 1}$ & 0.85 \\
Grain mill products & 204 & 0.68 & $\mathbf{1 . 1 0}$ & 0.72 \\
Glass and glassware pressed or blown & 322 & & 0.65 & 0.65 \\
Miscellaneous wood products & 249 & 0.63 & 0.63 & 0.63 \\
Paper mills & 262 & 0.60 & $\mathbf{0 . 6 7}$ & 0.61 \\
Dairy products & 202 & 0.57 & & 0.57 \\
Highway and street construction & 161 & 0.55 & & 0.55 \\
Fabricated structural metal products & 344 & 0.00 & $\mathbf{0 . 8 2}$ & 0.55 \\
Paperboard containers and boxes & 265 & 0.44 & 0.33 & 0.40 \\
Carpets and rugs & 227 & & 0.36 & 0.36 \\
Cement, hydraulic & 324 & 0.28 & & 0.28 \\
Fats and oils & 207 & 0.15 & 0.15 & 0.15 \\
Beverages & 208 & 0.35 & 0.13 & 0.15 \\
Gold and silver ores & 104 & 0.00 & & 0.00 \\
Commercial printing & 275 & & 0.00 & 0.00 \\
Average & & 0.87 & $\mathbf{1 . 7 6}$ & 1.28 \\
\hline
\end{tabular}

Note $:$ nec $=$ not elsewhere classified.

our model as well as by the earlier empirical literature. All variables, with the exception of regional experience that comes from the survey, are taken from Worldscope and are for 1993 (or the closest year for which the information is available). Further details about each of the variables are given in Appendix II.

Technological Sophistication. To capture the sophistication of an investor's technology, we use the ratio of its $R \& D$ intensity relative to the average value in its industry.

One caveat of using relative R\&D expenditure as a proxy for technological sophistication is that R\&D intensity is not a perfect measure of a firm's success in innovative activities. Furthermore, in low-technology sectors, differences between (small in general) R\&D activities may not have strong effects. Sophistication in terms of marketing skills and ownership of brand names may be far more important in some industries. To allow for this possibility and to explicitly account for the model's predictions regarding marketing/distribution costs, we also control for the investor's advertising intensity relative to the industry average.
To capture how important these intangible assets are for a particular industry, we include the average values of $R \& D$ and advertising intensity at the industry level. This allows us to take into account both intraindustry and interindustry effects. ${ }^{11}$

Firm Size. Blomström and Zejan (1991) suggest that smaller firms are less willing to take higher risks and are, therefore, more likely to enter a host country through a JV. Thus, we control for firm size and expect to find that it is negatively correlated with the probability of a JV.

Production Diversification. As Asiedu and Esfahani (2001) note, although a multinational may be well endowed in intangible assets, its role in its investment projects may be limited if these assets are spread over a wide range of

11. Note that the earlier literature usually employed either firm- or industry-level proxies for intangible assets. Asiedu and Esfahani (2001) included a firm-specific measure of all intangible assets (proxied by the ratio of sales to tangible assets) as well as industry-level R\&D intensity. None of the earlier studies controlled for intraindustry effects explicitly. 
industries. Following their suggestion, we control for production diversification and expect to find a positive sign on its coefficient, implying that diversification is positively correlated with the probability of a JV.

Regional Experience. Our model assumes that a JV partner contributes skills complementary to those of a foreign investor. The more familiar a foreign investor is with the region, the less the investor's need for a local partner. On the other hand, greater familiarity with a particular region may lower the cost of finding a suitable JV partner. Thus, the impact of regional experience on the propensity to seek a JV is unclear. To control for regional experience, we include a dummy variable taking on the value of 1 if a firm had a trading relationship with the region before 1990 and 0 otherwise.

International Experience. As Gatignon and Anderson (1988) and Blomström and Zejan (1991) show, firms with greater experience in foreign operations in general may be more adept in monitoring and dealing with local employees and thus may be less likely to share ownership. Since what matters is not just the countryor region-specific knowledge but overall international experience, we measure international experience by the share of foreign sales in a firm's total sales.

Host Country Characteristics. The choice between full and shared ownership is also likely to be influenced by a variety of host country characteristics (Asiedu and Esfahani 2001). Since the investigation of these issues is not of immediate interest to this study, we control for host country-specific factors with dummy variables for destination countries.

\section{Results}

Next, we turn to the regression results. Recall that in our probit model, the dependent variable equals 1 if investor $i$ has engaged in a JV with a local partner in country $k$ and 0 if the project is a direct entry. Thus, the number of observations is equal to the number of projects undertaken in the region by all firms in the sample. The estimated results are presented in Table 4 in terms of marginal effects.

The standard errors, listed in parentheses, are clustered for observations pertaining for the same company. As predicted, the results indicate that firms possessing more sophisticated technologies relative to the industry average are less likely to engage in JVs and prefer to retain full ownership of their investment projects (column 1). The same is true of firms with above-average investment in marketing and brand names (column 2). Both coefficients are statistically significant and remain so even when both proxies are entered into the same equation (column 3). As a robustness check, in column 4, we include dummies for three-digit SIC sectors and drop sector-specific variables. The coefficient on technological sophistication bears the same sign and remains significant, while the coefficient on relative advertising intensity loses its significance.

As for other explanatory variables, as anticipated, we find that JVs are more likely to take place in industries where intangible assets play a less prominent role (i.e., industries characterized by lower spending on $R \& D$ and advertising). Furthermore, they are more likely to be undertaken by smaller and more diversified firms. Regional and international experiences do not appear to have a statistically significant impact on the decision regarding the mode of entry.

One could argue that our empirical analysis suffers from a selection bias since we only consider projects that took place and ignore firms that decided against investment in a particular country or in the whole region. Thus, as a further robustness check, we estimate a two-stage model where the first stage (investment decision) describes the decision to invest and the second stage (ownership decision) examines the choice of mode of entry. The dependent variable in the first stage is equal to 1 if firm $i$ has undertaken FDI in country $k$ and 0 otherwise. In addition to all the determinants of the mode of entry described in the previous section, the first stage includes controls for host country characteristics commonly found in studies of FDI determinants. ${ }^{12}$ These are market size (proxied by population size), purchasing power of local consumers (captured by GDP per capita), quality of business environment (measured using the EBRD ratings of progress in transition process), corporate tax rate, openness to trade (defined as the sum of exports and imports divided by the GDP), and distance between source and host country.

12. See Wheeler and Mody (1992) and a survey of the literature on the determinants of FDI by Markusen (1995). 
TABLE 4

Results of a Probit Model_-JV versus Direct Entry

\begin{tabular}{|c|c|c|c|c|}
\hline Relative R\&D & $-0.055^{*}(0.033)$ & & $-0.069^{*}(0.041)$ & $-0.187 *(0.100)$ \\
\hline Industry R\&D & $-0.039^{* * *}(0.012)$ & & $-0.058^{* * *}(0.019)$ & \\
\hline Relative advertising & & $-0.166^{* *}(0.085)$ & $-0.244^{* *}(0.120)$ & $-0.317(0.232)$ \\
\hline Industry advertising & & $-0.007^{* *}(0.003)$ & $<.001(0.004)$ & \\
\hline Diversification & $0.037^{*}(0.021)$ & $0.022(0.022)$ & $0.043^{* *}(0.022)$ & $-0.057(0.043)$ \\
\hline Regional experience & $0.096(0.101)$ & $0.098(0.102)$ & $0.141(0.107)$ & $0.192(0.155)$ \\
\hline International experience & $-0.002(0.002)$ & $-0.002(0.002)$ & $-0.001(0.002)$ & $-0.005(0.003)$ \\
\hline Firm size & $-0.051^{*}(0.031)$ & $-0.062^{* *}(0.028)$ & $-0.086^{* *}(0.035)$ & $-0.063(0.059)$ \\
\hline Host dummies & Yes & Yes & Yes & Yes \\
\hline Industry dummies & No & No & No & Yes \\
\hline Observed $p$ & .60 & .56 & .57 & .51 \\
\hline Predicted $p$ & .61 & .57 & .57 & .52 \\
\hline No. of observations & 439 & 424 & 345 & 243 \\
\hline Pseudo $R^{2}$ & .14 & .13 & .21 & .41 \\
\hline Log likelihood & -255.07 & -254.04 & -185.61 & -98.75 \\
\hline
\end{tabular}

Notes: Dependent variable is equal to 1 for JVs and 0 for direct entry. The results are presented in terms of marginal effects evaluated at the sample mean. All models include a constant term that is not reported. Standard errors (clustered on firm) are listed in parentheses. <.001 denotes coefficients with absolute value below .001 .

*Significant at $10 \%$ level; **significant at $5 \%$ level; ***significant at $1 \%$ level.

The second stage includes all the variables used in the simple probit model plus two controls pertaining to host countries: transition progress and distance between the source and the host country. We expect to find a negative coefficient on the former variable, as the more advanced the host country in the reform process, the less need for help from a local partner to navigate through the bureaucracy to obtain the necessary permits and deal with tax authorities. Similarly, the smaller the distance between the home and the host country, the more familiar are foreign investors with the ways of doing business in their investment destination and thus again less need for a JV partner.

We estimate the two equations described above simultaneously by maximum likelihood (probit with sample selection), correcting standard errors for correlation between observations for the same firm. The number of observations in the first equation (investment decision) is equal to the number of firms in the sample, multiplied by the number of destination countries covered by the data set less observations with missing values. In the ownership decision equation, the number of observations is equal to the total number of FDI projects in the sample.

The results, presented in the first three columns of Table 5, lend support to our hypothesis.

In Table 5, the top panel contains the findings from the second stage (ownership decision), and it confirms that firms with more sophisticated technologies and marketing techniques are averse to sharing ownership and prefer to enter a host country directly. As before, the data indicate that JVs are less common in high R\&D- and advertising-intensive industries and among larger investors. Furthermore, there is some, albeit not very strong, indication that more diversified firms as well as those with less international experience tend to undertake JVs rather than enter directly. As expected, the data suggest that JVs are a less attractive option in economies more advanced in the transition process, where doing business is likely to be easier. Finally, regional experience and distance between the source and the host country do not appear to have a statistically significant impact on the ownership choice.

The investment decision equation, presented in the lower panel of Table 5, also produces the expected results. The findings indicate that larger firms and those operating in advertisingintensive industries are more likely to undertake FDI. The same is true of firms familiar with the region, possessing international experience and less diversified companies. ${ }^{13}$ In terms of host country characteristics, economies that are larger and more advanced in the transition process are more attractive investment destinations.

13. More diversified firms may be under less pressure to search for new markets. 


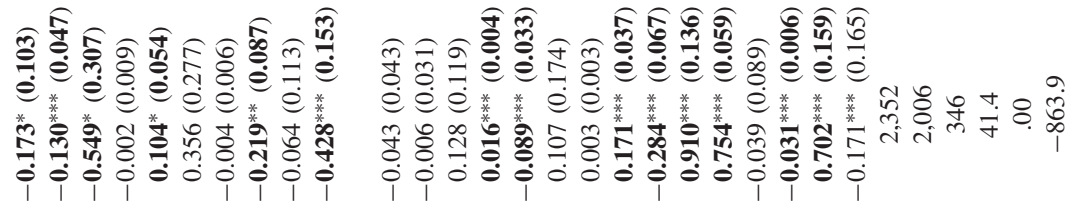

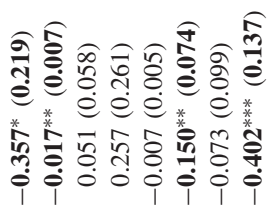

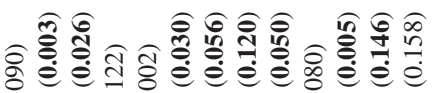

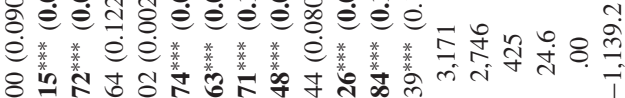

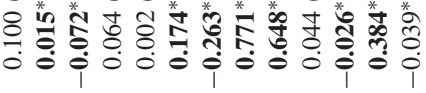

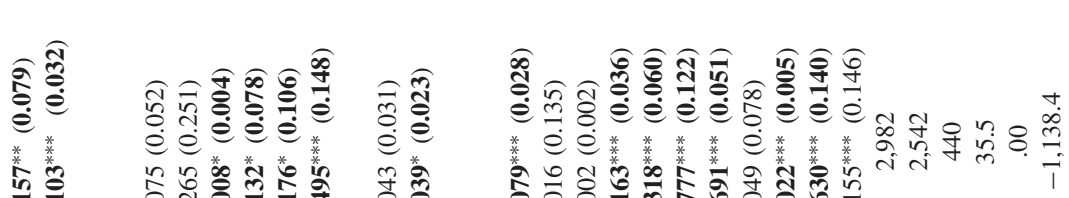

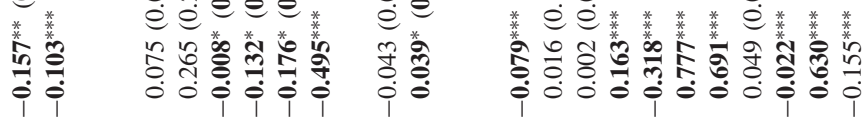

要要

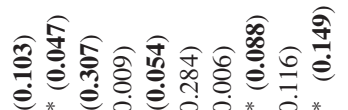

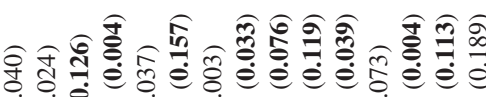

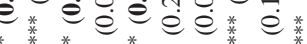

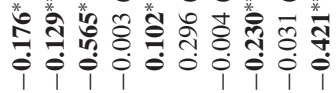

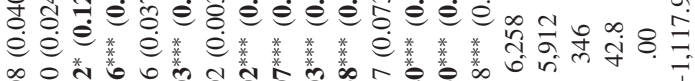

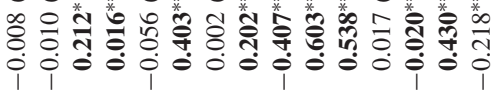

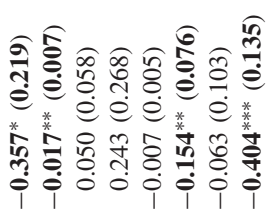

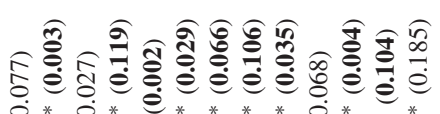

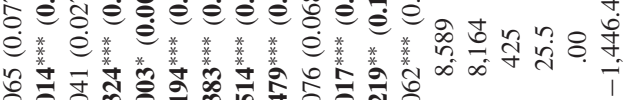

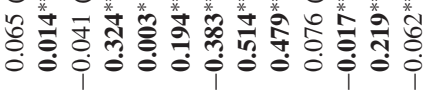

₹

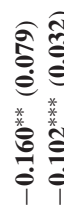

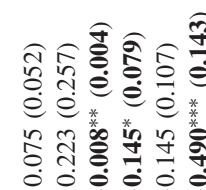

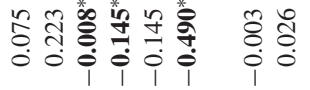

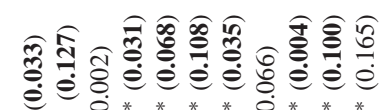

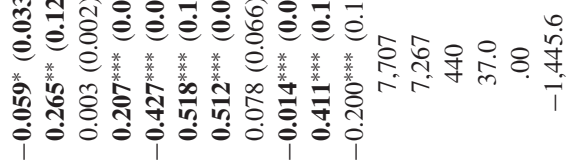

ले

io o o i 000 i

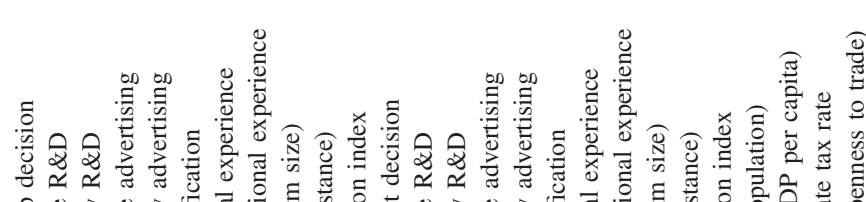

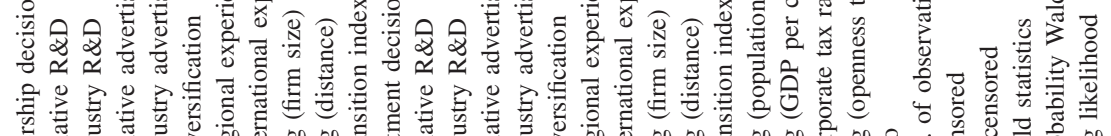


Similarly, less distant countries and those more open to trade and offering lower corporate tax rates are more successful at attracting FDI. On the other hand, GDP per capita, which may be a proxy for labor costs, does not appear to have impact on the investment decision.

As noted in Appendix II, firms that engaged in FDI in the region are oversampled in our data set. Therefore, as an additional robustness check, we reestimate the two-stage model, restricting our sample to investors, that is, firms with at least one investment in the countries considered in the study. A benefit of this restriction is that we reduce the number of 0 s on the left-hand side of the equation, as the original data set contains many firms that have not undertaken any investment projects in the region. These results, shown in the last three columns of Table 5, do not differ significantly from those obtained from the full sample. The variables of interest, technological and marketing sophistication, retain their signs, magnitudes, and significance levels, thus again lending support to our hypothesis.

Finally, we check whether the negative relationship between the technological sophistication and the choice of JVs could be driven by the fear of technology leakage due to less than perfect protection of IPRs in transition economies. To do so, we control in both the investment and the ownership decision equations for the strength of IPR protection in the host country. The extent of IPR protection is measured using an index of patent protection developed by Ginarte and Park (1997) and extended by Javorcik (2004b). The index refers to 1995 or the closest year for which the information was available. Its values range from 0 to 5 with the higher values indicating a stronger level of protection. The highest score in the group of countries under consideration is found in Hungary (3.75), while the lowest score of 2.52 belongs to Uzbekistan and former Yugoslav Republic of Macedonia. For a more detailed description of the index, see Appendix IIB.

The results of the augmented model are presented in Table 6. While we find that foreign investors are attracted to location with stronger IPR protection, we find no evidence of IPR legislation affecting the choice of entry mode. The coefficient on the IPR index is statistically significant in four of six specifications in the investment decision equation and in none of the six ownership decision equations. Other results remain pretty much unchanged. As before, we find that investors with more sophisticated technologies are less likely to engage in JVs, with this effect being statistically significant in all specifications. A similar pattern is found for marketing sophistication, though now it reaches conventional significance levels only in half of the cases.

\section{CONCLUSIONS}

The choice of entry mode by foreign investors has been of interest to both policy makers and researchers. Developing country governments are especially interested in the technology and know-how transfer that results from FDI. To be able to assess the potential magnitude of such benefits, it is important to understand preferences of different types of investors with respect to the entry mode. This study sheds some light on this issue by analyzing the intraindustry determinants of entry modes chosen by foreign firms entering transition economies of Eastern Europe and the successor states of the Soviet Union in the early 1990s.

Our empirical work is motivated by a simple theoretical model that allows for competition between asymmetric foreign investors. The model predicts that relatively efficient foreign investors are less likely to choose JVs and more likely to enter directly. The empirical results support this prediction. Thus, policies influencing FDI entry mode may affect technological content of the investment projects and generate different implications for the extent of potential spillovers to the host economy.

\section{APPENDIX I : DERIVATIONS AND PROOFS}

Here, we report all the analytical derivations and provide proofs for our results. Using the first-order conditions for Cournot competition,

$$
\begin{aligned}
\frac{\partial \pi_{i}\left(q_{i}, q_{-i}\right)}{\partial q_{i}} & =p(q)+p^{\prime}(q) q_{i}-c_{i} \\
& =a-b_{q-i}-2 b_{q i}-c_{i}=0 .
\end{aligned}
$$

We can easily calculate the equilibrium output levels:

$$
q_{i}^{x y}=\frac{a-2 c_{i}^{x}+c_{-i}^{y}}{3 b},
$$

where $i=1,2$ and $x, y=e, j$.

Furthermore, the equilibrium profit of a firm under regime $(x, y)$ is proportional to the square of its quantity. For example,

$$
\pi_{1}^{e j}=b\left[q_{1}^{e j}\right]^{2} \text { and } \pi_{2}^{e j}=\theta b\left[q_{2}^{e j}\right]^{2} .
$$




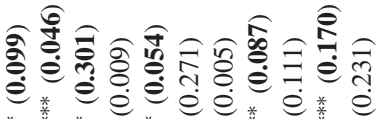

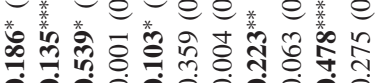

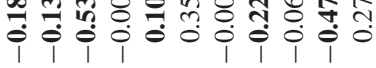

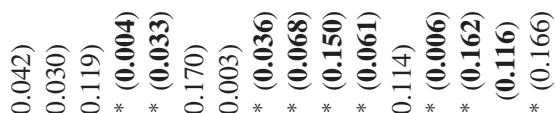

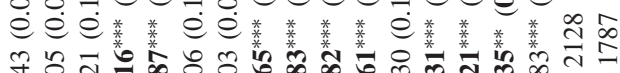

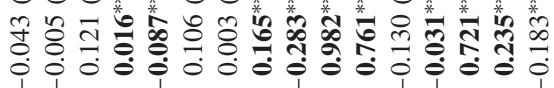

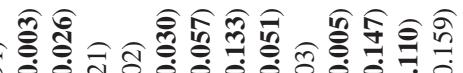

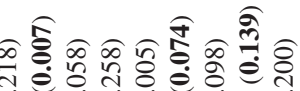

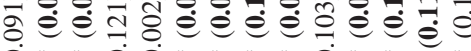

e $\dot{e} e$ e

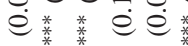

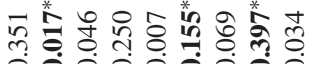

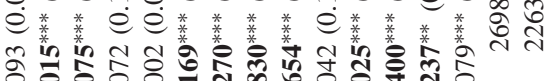
彳

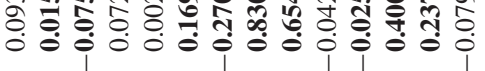

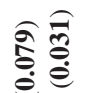

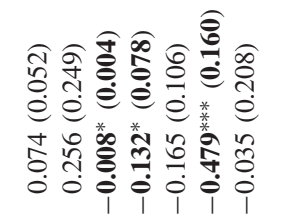

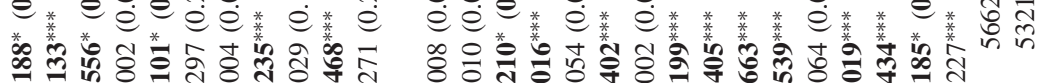
i.

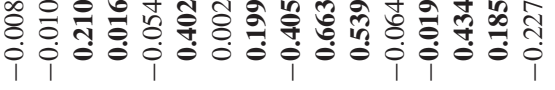

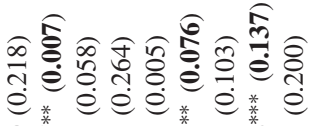

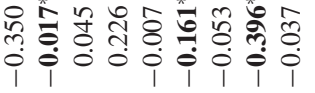

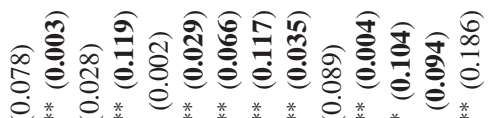

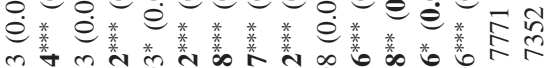

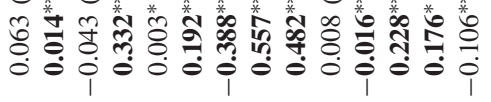
䔄气 e 巳 e é

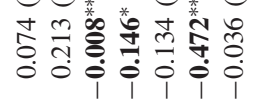

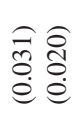

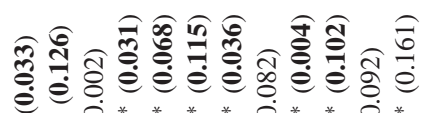
㠃

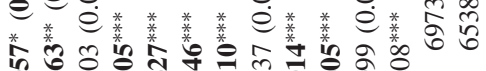

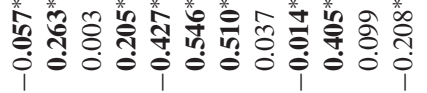

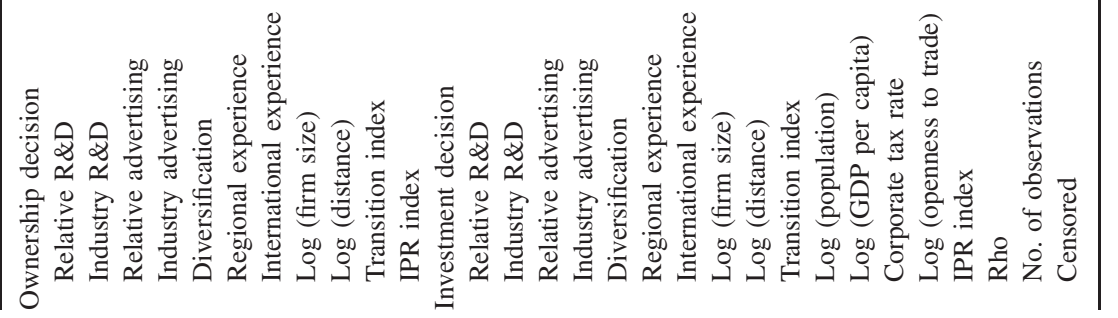


Thus, we have

$$
\begin{aligned}
u_{1} & =\left[\sqrt{b \theta} q_{1}^{j e}\right]^{2}-\left[\sqrt{b} q_{1}^{e e}\right]^{2}< \\
& =\left(\sqrt{\theta b} q_{1}^{j e}+\sqrt{b} q_{1}^{e e}\right)\left(\sqrt{\theta b} q_{1}^{j e}-\sqrt{b} q_{1}^{e e}\right)
\end{aligned}
$$

so that

$$
u_{1}>0 \text { iff } e_{1} \equiv \sqrt{\theta} q_{1}^{j e}-q_{1}^{e e}>0 .
$$

Using the equilibrium quantity levels given in Equation (6), we can describe the two incentive functions in terms of exogenous parameters. For example, $u_{1}()>$.0 iff $e_{1}>0$ where

$$
\begin{aligned}
e_{1}= & \sqrt{\theta}\left(a-2\left(\alpha_{1}+\delta \beta_{1}\right)+\alpha_{2}+\beta_{2}\right) \\
& -\left(a-2\left(\alpha_{1}+\beta_{1}\right)+\alpha_{2}+\beta_{2}\right) \\
= & (1-\sqrt{\theta})\left(-a+2 \alpha_{1}-\alpha_{2}-\beta_{2}\right)+2 \beta_{1}(1-\sqrt{\theta} \delta) .
\end{aligned}
$$

We can similarly show that

$$
u_{2}>0 \text { iff } e_{2} \equiv \sqrt{\theta} q_{2}^{e j}-q_{2}^{e e}>0,
$$

and

$$
\Delta_{1}>0 \text { iff } d_{1} \equiv \sqrt{\theta} q_{1}^{j j}-q_{1}^{e j}>0 .
$$

Finally,

$$
\Delta_{2}>0 \text { iff } d_{2} \equiv \sqrt{\theta} q_{2}^{j j}-q_{1}^{j e}>0 .
$$

As for the case of $u_{1}$, we can describe the above incentive functions in terms of exogenous parameters using Equations (1), (2), and (6).

\section{Proof of Proposition 1}

Note that

$$
\begin{array}{r}
\frac{\partial e_{i}}{\partial \alpha_{i}}=\frac{\partial d_{i}}{\partial \alpha_{i}}=\frac{2(1-\sqrt{\theta})}{3}>0 \\
\text { and } \frac{\partial e_{i}}{\partial \beta_{i}}=\frac{\partial d_{i}}{\partial \beta_{i}}=\frac{2(1-\delta \sqrt{\theta})}{3}>0
\end{array}
$$

and

$$
\begin{gathered}
\frac{\partial e_{i}}{\partial \alpha_{-i}}=\frac{\partial d_{i}}{\partial \alpha_{-i}}=-\frac{1(1-\sqrt{\theta})}{3}<0 \\
\text { and } \frac{\partial e_{i}}{\partial \beta_{-i}}=\frac{\partial d_{i}}{\partial \beta_{-i}}=\frac{1(1-\sqrt{\theta})}{3}<0 .
\end{gathered}
$$

\section{Proof of Corollary 1}

From Equations (8) and (9), we know that corollary 1 holds iff $e_{2}-e_{1}>0$. Substituting for the equilibrium output levels, we can show that

$$
\frac{\partial\left(e_{2}-e_{1}\right)}{\partial \theta}=-\frac{3\left(\alpha_{2}-\alpha_{1}\right)+\left(\beta_{2}-\beta_{1}\right)(1+2 \delta)}{6 \sqrt{\theta}}<0 .
$$

That is, $e_{2}-e_{1}$ is decreasing in $\theta$. Furthermore, at $\theta=1$, we have

$$
e_{2}-\left.e_{1}\right|_{\theta=1}=\frac{2\left(\beta_{2}-\beta_{1}\right)(1-\delta)}{3}>0 .
$$

Thus, it must be that $e_{2}-e_{1}>0$ for all $\theta$. Since $e_{2}$ is strictly greater than $e_{1}$, there exists parameter values for which only Firm 2 has a unilateral incentive for a JV. 
To prove the second statement of the corollary, it is enough to show that if $u_{1}>0$ then $\Delta_{2}>0$. We know that

$$
\frac{\partial\left(d_{2}-e_{1}\right)}{\partial \theta}=\frac{\left.3\left(\alpha_{1}-\alpha_{2}\right)-(1+2 \delta) \beta_{2}+3 \delta \beta_{1}\right)}{6 \sqrt{\theta}}<0 .
$$

That is, $d_{2}-e_{1}$ is decreasing in $\theta$. Furthermore, at $\theta=1$, we have

$$
d_{2}-\left.e_{1}\right|_{\theta=1}=\frac{2\left(\beta_{2}-\beta_{1}\right)(1-\delta)}{3}>0 .
$$

Thus, it must be that $d_{2}-e_{1}>0$ for all $\theta$. In other words, if Firm 1 has a unilateral incentive for a JV, Firm 2 will have a competitive incentive for a JV. As a result, the regime $(j, e)$ cannot be an equilibrium.

\section{APPENDIX II: DATA}

\section{A. Survey}

The respondents of the 1995 EBRD survey were asked to classify each of their existing or planned projects as a JV with a local partner, acquisition, or greenfield entry. For the purpose of this study, we classify all greenfield and acquisition projects not associated with JVs as direct entry. In other words, if a respondent listed more than one form of entry mode, the observation was classified as a JV if one of these forms was "JV with a local partner" and direct entry otherwise.

As a robustness check, we also used an alternative classification in which we created a separate observation for each entry mode reported by a respondent. Then, we estimated a probit model with the dependent variable taking on the value of unity for JVs and 0 for greenfield projects. The results on the variables of interest (i.e., $R \& D$ and marketing intensities) were very similar to those presented in Table 4. Furthermore, we also estimated a multinomial logit model with the dependent variable representing the three entry modes and a multinomial logit model with three entry modes plus the option of not investing at all. In both cases, the results on the impact of intangible assets on the choice between greenfield projects and JVs lent support to our hypothesis.

It is likely that firms that perceived the survey as more relevant (for instance, firms that had invested or considered investing in transition economies) were more likely to respond. To check this hypothesis, the list of major foreign investors in Poland compiled by the Polish State Investment Agency (1995) was examined. Poland was chosen for this exercise since it was the most popular destination country in the sample. Of 329 firms on the list, 118 received the EBRD survey and $50 \%$ of them responded, as opposed to the overall response rate for the survey equal to about $15 \%$. Statistical tests indicated that the means of firm-specific variables in the respondent and nonrespondent groups were not significantly different from each other. Thus, among the investing firms, the decision to respond to the survey was not systematically related to firm characteristics. Unfortunately, it was not possible to identify which among the firms that did not respond to the survey were not interested in undertaking investment in Eastern Europe and the former Soviet Union. There is no reason, however, to suspect that in the case of these firms, the decision to answer the survey was systematically related to their characteristics. Therefore, the data set can be treated as if the investing firms had been oversampled.

The survey did not ask about the date when each investment was undertaken. Since the magnitude of FDI inflows to transition countries was marginal before 1989 and the survey was conducted in January 1995, the information collected pertains mostly to the period 1989-94. Furthermore, to the best of our knowledge, none of the countries in the sample had legislation specifically forbidding full ownership by foreign investors. For instance, in the USSR, a presidential decree issued as early as October 1990 allowed foreign wholly owned companies to be established in the form of branches or subsidiaries. The decree also created the legal basis for foreign investors to buy out existing Soviet enterprises as these were privatized (McMillan 1996, 50). In Hungary, Act XXIV of 1988 on the Investment of Foreigners in Hungary allowed non-Hungarian companies to own equity up to $100 \%$ (WTO 1998). In Poland, the 1988 Law on Economic Activity with the Participation of Foreign Parties permitted $100 \%$ foreign equity participation (GATT 1992). It is possible, however, that in practice, permissions for fully owned projects may had been denied in some economies during the period covered by our sample. To control for this possibility, we included host country dummies in our model.

Since restrictions on the extent of foreign ownership may have been present in extractive sector and services, we excluded firms in the coal, gas, and oil industry from our sample. We also dropped projects in service industries, such as banking, insurance, telecommunications, accounting, public relations services, and so forth. In addition to possible restrictions on FDI, including these sectors would also pose some difficulties with measuring the endowment of intangible assets.

Note that our analysis assumes that all foreign investors have the option of engaging in a JV with a local partner, should they want to do so. In other words, the supply of local JV partners is not constrained, and the observed entry patterns are determined entirely by foreign investors' demand. Considering that the aggregate FDI inflows into transition economies were quite small during the period covered by our sample, this assumption is quite realistic.

\section{B. Other Data Sources}

All firm-specific explanatory variables used in the analysis, with the exception of regional experience that comes from the survey, were taken from the commercial database Worldscope and are for 1993 (or the closest year for which the information is available). Note that the variables pertain to the characteristics of the parent companies, not their particular subsidiaries in the regions. Details of variable definitions are listed below.

Firm size: Log of firm sales in millions of U.S. dollars.

Relative technological sophistication: Firm R\&D intensity/average $R \& D$ intensity in the industry.

$R \& D$ intensity is measured by $R \& D$ expenditure expressed as a percentage of total sales. To calculate industry averages (at the three-digit SIC industry classification), we use figures for all firms listed in Worldscope in a given 
industry, not just firms included in our sample. Thus, these values correspond to the average $R \& D$ intensity of major firms operating in developed countries in a given industry.

Relative marketing sophistication: Firm advertising intensity/average advertising intensity in the industry.

Advertising intensity is defined as the ratio of sales, general, and administrative expenditure to total sales, which is a standard proxy used in the literature. The industry average is again calculated at the three-digit SIC level.

Product diversification: The number of four-digit SIC codes describing a firm's activities.

International experience: The share of foreign sales in a firm's total sales. Ideally, we would like to use the share of foreign assets in a firm's total assets. However, using this measure would severely reduce the size of our sample. The share of foreign sales is highly correlated with the share of foreign assets (correlation of .82). Thus, our proxy for international experience seems reasonable.

Population size, GDP per capita: Both variables enter in $\log$ form, pertain to 1993, and come from EBRD (various issues).

Transition indicators: The transition indicators rate the progress of a country's reforms in the following areas: price liberalization and competition, trade and exchange system, large-scale privatization, small-scale privatization, enterprise restructuring, and banking reform. See $\operatorname{EBRD}(1994,11)$ for a detailed description. In the empirical analysis, a simple average of the EBRD indicators is used.

Openness to trade: $\log$ (exports + imports)/GDP is calculated using figures from the World Bank World Development Indicators.

Corporate tax rate: Expressed in percentages, corresponds to the highest rate applicable in the host country. Source: PriceWaterhouseCoopers.

Distance: Log distance between the capital cities expressed in kilometers. The following source countries are included in the sample: United Kingdom, United States, Germany, France, Finland, Switzerland, Denmark, Norway, the Netherlands, Austria, Sweden, Belgium, Canada, Japan, Australia, Italy, Greece, Ireland, Portugal, Singapore, Spain, Brazil, Malaysia, South Africa, and South Korea.

Index of IPR protection: Originally developed by Ginarte and Park (1997) and later extended by Javorcik (2004b). The index takes into account five aspects of patent laws: (1) extent of coverage, (2) membership in international patent agreements, (3) provisions for loss of protection, (4) enforcement mechanisms, and (5) duration of protection. Each of the categories is assigned a value between 0 and 1 , and the unweighted sum of these values constitutes the patent rights index. The index ranges from 0 to 5 with the higher values indicating a stronger level of protection. The index refers to 1995 or the closest year for which the information was available.

\section{REFERENCES}

Al-Saadon, Y., and S. P. Das. "Host-Country Policy, Transfer Pricing and Ownership Distribution in International Joint Ventures: A Theoretical Analysis." International Journal of Industrial Organization, 14, 1996, 345-64.
Asiedu, E., and H. S. Esfahani. "Ownership Structure in Foreign Direct Investment Projects." Review of Economics and Statistics, 83, 2001, 647-62.

Blomström, M., and F. Sjöholm. "Technology Transfer and Spillovers: Does Local Participation with Multinationals Matter?" European Economic Review, 43, 1999, 915-23.

Blomström, M., and M. Zejan. "Why Do Multinational Firms Seek Out Joint Ventures?" Journal of International Development, 3, 1991, 53-63.

Blomström, M., R. E. Lipsey, and L. Ohlsson. "What Do Rich Countries Trade with Each Other? R\&D and the Composition of U.S. and Swedish Trade." NBER Reprint No. 1551. Banca Nazionale del Lavoro Quarterly Review, 173, 1991, 215-35, June 1990.

Caves, R. E. Multinational Enterprise and Economic Analysis. Cambridge: Cambridge University Press, 1996.

EBRD (European Bank for Reconstruction and Development). Transition Report. London: EBRD, 1994.

Ethier, W., and J. Markusen. "Multinational Firms, Technological Diffusion and Trade." Journal of International Economics, 41, 1996, 1-28.

Gatignon, H., and E. Anderson. "The Multinational Corporation's Degree of Control over Foreign Subsidiaries: An Empirical Test of a Transaction Cost Explanation." Journal of Law, Economics, and Organization, 4, 1988, $305-36$.

GATT (General Agreement on Tariffs and Trade). Trade Policy Review: Poland, Vol. 1. Geneva, Switzerland: GATT, 1992.

Ginarte, J. C., and W. G. Park. "Determinants of patent rights: A cross-national study." Research Policy 26, 1997, 283-301.

Gomes-Casseres, B. "Ownership Structures of Foreign Subsidiaries; Theory and Evidence." Journal of Economic Behavior and Organization, 11, 1989, 1-25.

Horstmann, I. J., and J. R. Markusen. "Endogenous Market Structures in International Trade (Natura Facit Seltum)." Journal of International Economics, 32, 1992, 109-29.

Javorcik, B. S. "Does Foreign Direct Investment Increase the Productivity of Domestic Firms? In Search of Spillovers through Backward Linkages." American Economic Review, 94, 2004a, 605-27.

- "The Composition of Foreign Direct Investment and Protection of Intellectual Property Rights: Evidence from Transition Economies." European Economic Review, 48, 2004b, 39-62.

- "Technological Leadership and Foreign Investors' Choice of Entry Mode," in Global Integration and Technology Transfer, edited by B. Hoekman and B. Javorcik. New York: Palgrave Macmillan, 2006, 179206.

Javorcik, B. S., and M. Spatareanu. "To Share or Not To Share: Does Local Participation Matter for Spillovers from FDI?" Journal of Development Economics, 85, 2008, 194-217.

Javorcik, B. S., and S.-J. Wei. "Corruption and Cross-Border Investment in Emerging Markets: Firm-Level Evidence." Journal of International Money and Finance, 28, 2009, 605-24.

Klimenko, M., and K. Saggi. "Technical Compatibility and the Mode of Foreign Entry under Network Externalities." Canadian Journal of Economics, 40, 2007, $176-206$.

Mansfield, E., and A. Romeo. "Technology Transfer to Overseas Subsidiaries by U.S. Based Firms." Quarterly Journal of Economics, 95, 1980, 737-49.

Markusen, J. R. "The Boundaries of Multinational Enterprises and the Theory of International Trade." Journal of Economic Perspectives, 9, 1995, 169-89. 
"Contracts, Intellectual Property Rights, and Multinational Investment in Developing Countries." Journal of International Economics, 53, 2001, 189-204.

Mattoo, A., M. Olarreaga, and K. Saggi. "Mode of Foreign Entry, Technology Transfer, and FDI Policy." Journal of Development Economics, 75, 2004, 95-111.

McMillan, C. H. "Foreign Investment in Russia: Soviet Legacies and Post-Soviet Prospects," in Foreign Investment in Russia and Other Soviet Successor States, edited by P. Artisien-Maksimenko and Y. Adjubei. New York: St. Martin's Press, 1996, 41-72.

Miller, R., J. Glen, F. Jaspersen, and Y. Karmokolies. "International Joint Ventures in Developing Countries:
Happy Marriages?" IFC Discussion Paper No. 29, 1996.

Polish State Investment Agency. Major Investor List. Warsaw: PSIA, 1995.

Ramachandran, V. "Technology Transfer, Firm Ownership, and Investment in Human Capital." Review of Economics and Statistics, 75, 1993, 664-70.

Wheeler, D., and A. Mody. "International Investment Location Decisions: The Case of US Firms." Journal of International Economics, 33, 1992, $57-76$.

WTO (World Trade Organization). Trade Policy Review: Hungary. Geneva, Switzerland: WTO, 1998. 